\title{
Can Aid Generate Growth in Africa?
}

\author{
by \\ Arne Bigsten \\ Department of Economics \\ Göteborg University \\ Working papers in economics no 3
}

\begin{abstract}
The paper discusses the impact of foreign aid on economic growth in Africa. After brief discussion about growth determinants it goes on to review the available evidence about the impact of aid on African economic growth. Evidence from both cross-country regressions and country studies is considered, and issues relating to economic policy, governance, ownership, and sustainability are identified as particularly important. Given those insights, some general conclusions are drawn as to what type of aid should be given. However, the main focus is on a discussion about how to structure the aid relationship so that it encourages good governance, which is deemed essential for long-term growth. Donors should delegate more responsibility to the recipients, while at the same time creating an incentive structure for good performance. This would include among other things a shift towards ex post conditionality and aid allocation according to performance. Given the improvements in the economic policy environment in Africa, the prospects for effective aid look more promising than they have for a long time.
\end{abstract}

Keywords: Aid, Growth, Africa

JEL-classification : O19

Göteborg University

Department of Economics

P.O. Box 640

SE 40530 Göteborg

Tel: + 46317731358

Fax: + 46317731326

E-mail: Arne.Bigsten@economics.gu.se 


\section{The Problem}

The objective of aid is to improve the standard of living of poor people. Long term, and sustainable welfare improvements require economic growth. The link between aid and growth is complex, so it has been difficult to measure the growth impact of aid. The problem is to measure the impact, while controlling for other factors that influence growth. However, there are some recent econometric analyses that deal quite effectively with the issue.

This paper aims to do three things. First, there is a brief discussion about growth determinants in Africa. Second, against this background we review various types of evidence about the impact of aid on growth. Third, based on the evidence we discuss the implications for aid to Africa from different perspectives. Should aid continue, and, if so, what kind of aid and what type of aid relationship may be effective. The paper ends with some concluding remarks.

\section{What Determines Growth?}

The rate of growth of any economy is determined by the accumulation of physical and human capital, the efficiency of resource allocation, and the ability to acquire and apply modern technology. What is required for faster growth is change in the economic environment that facilitate both the accumulation of production factors and their efficient allocation, and the introduction of better technologies. There are by now extensive evidence that this requires economic policies at the micro level to develop and sustain efficient markets, while macro policy must be geared to guarantee macroeconomic stability. An efficient economy also requires a supporting environment of efficient institutions.

Investment is a necessary, but not sufficient, condition for growth. A major aim of recent African adjustment programmes has been to increase private sector investment, but uncertainty and lack of credibility as well as low returns have held it back. Still, the macroeconomic environment has been improved in a number of countries, and this will, if the improvements can be sustained, help revive investment.

There have been large distortions in the incentive structures in many African economies, and that consequently resources have been poorly allocated. The reform programmes have reduced distortions, but, so far, the growth impact has been limited. Adam and O'Connell (1997) note that there exist distortions which affect the composition of investment. Typically policy favours public 
over private investment, foreign over domestic, and import-substituting industry over export agriculture. There is also a differential treatment of investment non-taxed informal and taxed formal activities. These distortions have been reduced somewhat, but they still distort resource allocation and reduce growth.

A central question is why growth supporting institutions develop. A government which is primarily concerned with its own survival does not necessarily set up ownership rules that are good for economic growth. With special interest politics at centre stage, there is bound to be static inefficiency due to distortions, investors are going to be cautious, and resources are going to be wasted in rentseeking activities.

In African economies there is a very pervasive influence of politics on economics. Many discretionary policy interventions have paved the way for corruption and rent-seeking (Bigsten, 1993), and elites have also used the system to allocate rents as a means of securing their power positions (Bigsten and Moene, 1996). Adam and O'Connell (1997, p. 17) conclude from their analysis of the relationship between taxation and investment that "the distortionary effects of tax and uncertainly emanate in the main from the structure of political regimes in African economies, and that these structures may act as an impediment to rapid evolution of institutions which otherwise might mitigate the effects of politically motivated uncertainty on investment and growth."

A notion that appears many times in the analysis of the Asian miracle is "shared growth", that is, the mass of the population must see the benefits if they are going to participate actively. It is not only the general citizen who must be included, but also the ruling elite must tolerate competing elites. The fear of opposition and desire for total control has stifled many initiatives in African countries.

For shared growth to come about, there is need for a bureaucracy of high quality, which is sufficiently insulated from vested interests. Such an institutional set-up is not easily created, but the opening up of the political arena should support such a change. Growth is thus determined by investment in physical and human capital, technical progress, and the effectiveness of resource allocation. Changes in these factors do in turn depend on the character of the policy environment, institutions and governance. We will discuss the impact of aid on these variables, and we will also consider how the character of the aid relationship affects the growth impact of aid. 


\section{Two Decades of Stagnation}

During the 1980s and first half of the 1990s per capita incomes in sub-Saharan Africa fell by $1.3 \%$ per year. Africa stands out as the worst performing region in the world. African economies have invested a smaller share of GDP than comparable regions, and a smaller share of investments have gone to the private sector. One third of the growth gap vis a vis other LDCs may be explained by lower investment rates, but the remaining two thirds were due to slower productivity growth (Collier and Gunning, 1997). Investment in Africa seems to be less efficient that investment in comparable regions. It is estimated that incremental capital output ratios are one quarter of those in East Asia and between half and two thirds of those in other LDCs (Adam and O'Connell, 1997).

So what are the characteristics that set Africa apart? First, private agents in Africa face atypically high risks and poorly functioning governments. Taxes and tax like distortions are high and volatile. The natural environment in Africa is very risky, and there are also risks associated with the difficulty in enforcing contracts. Institutions that reduce the costs of contract enforcement and other transaction costs have not yet evolved. Few of the risks are insurable because of asymmetric information. Firms are less diversified, which means that they are highly exposed to shocks. In some cases they may be physically unable to honour cataracts. These difficulties have created a behaviour that in some instances is detrimental to growth. In a high risk environment without formal insurance and credit markets, agents try to protect themselves for example via diversification, accumulation of assets for consumption smoothing, and by building informal insurance arrangements. High risk, poor public services and lack of social capital combine to constrain growth.

A major factor behind the lack of investment response to economic reforms undertaken in Africa during the 1980s and 1990s is the high risks associated with investment in Africa. The risk rating of the Institutional Investor for Africa has actually deteriorated over time from 31.8 in 1979 to 21.7 in 1995 (on a scale from 0 to 100). Increasing uncertainty tends to make investors avoid irreversible investments (at least for a while) and try to achieve ex ante consumption smoothing. Particularly in African agriculture self-insurance mechanisms are prevalent, and these tend to lower growth. 
Investors choose to go for liquid and safe investments, with negative consequences for growth. One issue of interest in this context may then be to what extent aid can help reduce risks and to increase stability. Here, however, it has been noted that the high aid inflows may have reduced the ability of genuine reforming governments to signal their intentions of sustained reform (Rodrik, 1989), which has meant that investor confidence has not been built up.

There is also a time-consistency problem. Ex post it may be beneficial for governments to change their decisions about for example tax rates. To the extent that firms realize that this may happen, they may try to protect themselves by shifting away from savings to consumption or to less taxable forms of capital. This lowers investments and the growth rate. Political structures that stimulate predatory behavior aggravate the time consistency problem.

Other reasons for low investment during the reform period may be that the countries started from a disequilibrium capital stock, or that it takes a long time to build up confidence after civil war. If aid can help guarantee stability, it may make the countries more attractive to foreign or domestic investors.

\section{Cross-Country Evidence on the Impact of Aid on Growth}

As a share of GDP Sub-Saharan Africa receives nearly five times more aid than any other region. The share of aid to GDP was on average 16\% in 1994, while it is as high as $101 \%$ in Mozambique and $30 \%$ in Tanzania. One reason for the high gross flows is, of course, the high debt burden that was accumulated by many countries from the mid-70s onwards. A lot of this has had to be written off or converted to soft loans, and this has required large gross flows of resources, a large part of which then has flowed back to the international financial institutions, the World Bank and the IMF. For example, while Zambia in the early 1990s received an annual gross inflow of close to \$1,500 million, the net ODA was only about $\$ 300$ million (Bonnick, 1997, p. 115). The share of debt service to exports was $174 \%$ in Zambia in 1995 . The increasing aid dependence is contrary to the long-term aim of donors, which is to increase self-reliance and to get to a point where countries can grow from their own resources. Aid dependence has a range of effects that might be detrimental to long term development efforts. 
Africa would be in a position to reduce its aid dependence if it had better access to the international private capital markets, but in spite of dramatic increases in flows to the LDCs generally, Africa has been passed by. Investors view Africa as a capital hostile continent, and even Africans themselves hold vast sums of money outside the continent (Claessens and Naude, 1993). Aid to some extent may compensate for this, but the aid flows are not a perfect substitutes for private investment resources, which normally come on other conditions and together with technological skills and other forms of knowhow.

What kinds of effects of aid on growth are possible to discern? One possible approach is to distinguish between direct and the indirect effects of aid. The direct effects alter production, incomes or consumption as a direct consequence of some project or intervention, while the indirect effects are less easily identified. Aid to public sector projects, for example, releases resources which can be used for cuts in taxation and borrowing, or increases in expenditures. The private sector is indirectly affected, for example, via changes in relative prices. Aid may also affect the policy environment.

Both via direct and indirect channels aid may have an effect on investment. Since the long term aim of aid is that the recipient country should grow from its own resources, the impact of aid on domestic resource mobilization is also essential. Domestic savings and tax efforts are two important variables to consider. Another concern is the development of exports, which in the longer term is a necessary prerequisite for self-sustained growth. Via Dutch Disease effect aid may make exports less competitive and aggravate the inward orientation. However, during the recent period of economic reforms the appreciation effect of aid has been counteracted by the effects of the liberalization of the foreign exchange market (see e.g. White, 1998).

Many authors have tried to use simple regressions to establish a link between aid and growth on some cross-section of countries, but the result has generally been that there is no significant correlation between the amount of aid and growth (Mosley, 1987, Riddell, 1987, White, 1992, 1998). At the same time, project evaluations show that the majority of projects are successful. This conflicting evidence has been referred to as the macro-micro paradox. One explanation of the paradox could be that the direct effects of aid are positive, while it tends to have negative indirect effects. 
Neither Mosley, Hudson, and Horrel (1987), nor Boone (1994, 1996) were able to find any significant growth effect of aid in cross-country regressions. The most ambitious attempt at measuring net effects on growth is due to Burnside and Dollar (1997), who use a more sophisticated approach than previous analysts and model explicitly the interactions among aid, policy, and growth. The main question that they address is whether the effect of aid on growth depend on the policy environment. They also consider whether donors allocate aid in favour of countries with good policies and whether aid has affected policies.

Burnside and Dollar use two stage least squares to estimate simultaneously equations for growth, aid, and policy. By making identifying assumptions about the exogenous determinants of aid, policy and growth, they can determine the separate effects of aid and policy on growth. They are also able to test whether aid influences policy or vice versa.

The explanatory variables also include an index of institutional quality that captures the role of property rights and the efficiency of the government bureaucracy. They further introduce a variable for ethnic fractionalization, which has turned out to be significant in other regressions, the frequency of assassinations to measure civil unrest, and a variable for inefficiency of the financial system. The policy variables are trade openness ( a dummy due to Sachs and Warner, 1995), inflation, the share of the budget surplus in GDP and the share of government consumption in GDP. Education was not significant when tried.

They obtain robust results with regard to the impact of institutional quality, inflation and trade openness. Government consumption had a weakly negative effect. When aid was entered directly it had no significant effect. When it was interacted with the policy index, however, it was significant. The authors allow for the fact that aid is skewed towards poorly growing countries by instrumenting aid with population and donor interest variables. ${ }^{1}$

The study does show that aid has positive effects on growth in the good policy environment, while it does not work in distorted environment. When one controls for aid allocation more aid goes to countries with good policies. This is particularly true for multilateral aid, while bilateral aid is more steered according to donor interest variables. Government consumption increases with bilateral aid,

\footnotetext{
${ }^{1}$ To capture donors's strategic interests Burnside and Dollar use dummies for Sub-Saharan Africa, the Franc zone, Egypt and Central America and a measure of arms imports lagged one period.
} 
but it is not possible to show that aid that increases government spending has a positive growth effect.

There does not seem to be any systematic impact from aid to policy. For example, in Ghana good policies were rewarded, while in the case of Zambia aid increased between 1970 and 1993, while policies deteriorated throughout. It appears, however, to be the case that donors do reward good policy.

Burnside and Dollar thus found that aid significantly increased growth in good policy environment (measured by a composite measure of macroeconomic policies), had no effect in average environments and was actually damaging in bad policy environments. The evidence on the impact of aid on investment is mixed, but there is not clear evidence that aid contributes significantly to higher private investment.

There are of course limits as to what you can establish on the basis of cross-country regressions using highly aggregate data. It may well be that such regressions fail to pick up some of the positive effects suggested to exist by micro evaluations. Still, it is hard to argue that aid has, so far, been very effective in stimulating growth in Africa. The evidence suggesting that this poor result to a high degree is due to the type of economic policy and the institutional environment seems convincing. We will discuss the implications of this insight for aid below.

\section{The Case of Tanzania ${ }^{2}$}

Tanzania is one of the major recipients of aid in Sub-Saharan Africa. It is also a country that has had a high profile internationally and which has pursued a high interventionist development strategy. The result of this has been disappointing, however. Official GDP estimates suggest that real incomes per capita in Tanzania are not much different now then they were in 1970. The pattern is one of stagnation over the 1970s, dramatic reduction in incomes during the crisis period of 1979-85, and slow but definite growth during the reform period starting in 1986.

What can one say about the effect of aid on growth determinants in Tanzania? If we first consider physical capital formation, it is obvious that aid in the 1970's contributed to a high investment rate, but because of the inward-looking, state-directed strategy, the quality of investments became low. Investments declined only moderately in the crisis period, although capacity utilization fell

\footnotetext{
${ }^{2}$ This section draws on Adam et al (1994a).
} 
dramatically. Finally, there has been a dramatic increase in capital formation since the reforms started in the mid-1980s. The quality of investments is higher than in the previous period, but still generally low. This may be due to the fact that there still have been only relatively small changes in ownership and the orientation of investment, that is, parastatals still play a large role.

Early attempts of donors to support industry directly did not fare well, and there has been a shift from direct support to indirect support of productive activities. A substantial share of aid has therefore in recent years gone to investments in, and rehabilitation of, economic infrastructure. These investments show good returns, and they also help to create an enabling environment for economic activities. It seems obvious that aid has made it possible for Tanzania to achieve higher investment rates than what would otherwise have been possible.

The major areas of human capital formation that are relevant are health and education. Although the results of projects in these areas have been mixed, the projects undertaken contributed to the early improvements in the supply of skills in Tanzania. Unfortunately, it has been difficult to sustain the advances and many of the achievements of the 1970's have since been eroded. The budget support provided in recent years has at least helped to contain the decline of the public educational system, but it is certainly in a very poor state.

Apart from transferring external resources into the country, aid also has an effect on policy formation. This indirect effect may at times be more important than the direct resource transfer effect. It could be both positive and negative. Aid in the 1970's and in the first half of 1980s indirectly supported a strategy that later turned out to be unviable. Donors gradually became more and more critical in the early 1980's, particularly with regard to the appreciated exchange rate. For example, Sweden was reluctant to join in the critique and, together with other sympathetic donors, Sweden probably helped make it possible for the traditionalists in the Tanzanian government to delay economic adjustment. In this period it is therefore probably fair to say that, although the direct effects of aid were positive, these were counteracted by the negative indirect effect of preserving a policy regime detrimental to growth. The latter effect is impossible to quantify. Still, the costs of delayed reforms may have been substantial. However, since about 1986 aid has increased in support of market reforms, and for this period the impact of aid on the policy environment has instead been decidedly positive. The donors in this period have been essentially in agreement about the requirements for aid to Tanzania. 
Much of the aid in recent years has been geared to support the economic reform programme. Poor governance is obviously a severe problem in Tanzania today, and the poor quality of the public administration must certainly have retarded economic growth. Efforts to support public sector management probably have been beneficial, but such effects are hard to measure.

The ability of the country to sustain long-term economic growth and to reduce its current, very high aid dependency will depend on the levels of domestic savings, tax revenues and export performance. The domestic savings rate appears to have gone down during the recent aid boom, but the data is very shaky. Still, this is the effect one would expect to see. It should be noted, however, that at the same time there has been an investment boom, so there has not been any dramatic increase in the consumption share.

Finally, we have the issue of export performance. There is considerable evidence showing that export success is closely related to economic growth, and if aid has effects that are detrimental to exports, this is a serious problem. The focus of the discussion has been the so called Dutch disease effect, which is that aid inflow leads to an appreciation of the real exchange rate. During the Nyerere years the whole policy package was highly biassed against exports, but this package was basically not aid driven. Still, by making it possible to finance imports, aid did support an overvalued exchange rate, and it probably also helped extend the period of inward orientation. In the first years of the reform period, aid increased dramatically, while at the same time the real exchange rate depreciated a lot. Then aid supported pro-export reforms. Now the exchange rate is market determined, which means that aid inflows will tend to have an appreciating effect on the exchange rate.

Looking at the growth record of Tanzania, it is hard to argue that aid has had a positive effect on economic growth over the period as a whole. The growth rates recorded depend mainly on factors other than foreign aid. The country for a long time followed a development strategy that turned out to be unviable, and the economy has also been exposed to a series of external shocks. It is not possible to disentangle the overall growth effect of aid in this context. We have looked at the relationship between aid and the factors that are important for economic growth. We have pointed out that the direct effects of resource transfers in most cases are positive, although the effects have often been smaller than expected. We have then argued that the indirect effects on policy are very important. Here, it is possible that the aid of Sweden and other like-minded donors made it possible to delay adjustments in the first part of the 1980's, and thereby exerted a negative influence on growth. Since 
the mid-1980's, however, this situation has been reversed, and aid has supported sensible policy changes. It is reasonable to assume that the growth effect of aid in this new environment has been positive.

\section{Ownership and Sustainability}

A major concern of recent analysts of aid and development has been the high degree of external control of reform programmes, and the limited domestic commitment. Zambia is a case in point. During the 1980s the lending of the World Bank and also other donors focussed on balance of payments support for structural adjustment. The government for each new programme agreed to undertake reforms, but in the end it did not. The country was unable to diversify exports and to increase growth.

The Chiluba government that took power in 1991 has brought inflation under control and restored the discipline in debt management. Privatization, diversification of production, rehabilitation of economic infrastructure and improvements of social services has been harder to bring about, and poverty has increased. By August 1992 debt had fallen by $\$ 1.5$ billion to $\$ 6.5$ billion due to Paris Club rescheduling and debt cancellations by bilateral creditors. Larger IDA commitments have reduced the debt service burden. Commercial and short-term debt has been reduced through debt-buy back operations that reduced the exposure to London -club debtors. Also Paris Club creditors have provided significant debt relief. Zambia's credit worthiness has improved and arrears have been reduced.

The World Bank's own evaluation of its assistance to Zambia concludes that too much emphasis has been put on short term stabilization and not on long-term growth, and that there has been insufficient and unrealistic analysis of the political situation as well as overoptimism. ${ }^{3}$ When evaluating different projects undertaken in Zambia the Bank concludes that portfolio performance compares unfavourably with the region and bank lending overall. Many projects had poor sustainability ratings. Particularly projects in agriculture have had very unsatisfactory results.

The evaluation of bank lending concludes that successful projects have tended to a) be small and not management intensive; b) have appropriate technology; and c) use foreign contractors/consultants

\footnotetext{
${ }^{3}$ For an analysis of Swedish aid to Zambia, see Adam et al (1994b).
} 
and involve some training of nationals. The unsuccessful projects, mainly in agriculture, a) depended on weak administration and management; b) required counterpart funds; c) suffered from imperfect delegation of authority; and d) presented coordination problems among agencies with unclear responsibilities (Bonnick, 1997, p. 8).

These results are rather typical of the problems that have faced donors in Africa. When projects are in a limbo between donors and recipients and no one is fully responsible, they tend to perform poorly. One way to go is then for the donor to take full control. Then they can make the projects work for the period that they are in charge, but the sustainability of the projects in the longer term is highly uncertain. The alternative approach is to put responsibility more squarely with the recipient, which should enhance project sustainability. The Bank and other donors have in recent years attempted to increase Zambian ownership of the development programmes, by giving the Zambian authorities a greater responsibility for coordination and implementation. The pattern is the same throughout Africa, but the results are as yet uncertain.

An interesting analysis of sustainability has been undertaken by Paldam (1997), who has revisited Danish bilateral projects in nine countries five years after their completion. He has constructed a scale according to which has ranked the degree of project success. He tries to figure out whether it was worthwhile to undertake the project or not, but notes that it is hard to evaluate the projects against the multiple, unweighted, vague and qualitative goals of Danish aid. The main result is that the average project is barely worth undertaking. The likelihood of failure increases very strongly if the project either is done in Africa, is in agriculture, or is done within a parastatal arrangement. Social sector projects do better. There is also some weak evidence that NGO projects do better and that small projects are more often successful than large ones. The environment of the projects is also believed to be important, but the limited sample size make it impossible to show this conclusively.

Paldam reaches the depressing conclusion that "the average project in Africa fails" (p. 10). He notes two obvious aspects of the Africa-problem. There is a maintenance problem. It is very hard to organize maintenance activities in Africa in an effective way, which means that projects deteriorate much faster in Africa than elsewhere. This is of course revealed in an evaluation that takes place five year after the completion of the project. Second, there is again a project-ownership problem due to the long periods of high degree of aid-dependence. 
Since the analysis essentially covers projects that were completed in the late 1980s, it is somewhat uncertain whether the results from that period are a good guides as to what donors could achieve today. First, there has been a process of learning by doing, that is donors have learnt from past mistakes. Second, there have been extensive macroeconomic reforms in Africa creating a much less distorted and more liberal economic environment. This would make it easier to undertake projects as we have noted above.

\section{Aid and Governance}

The recent debate on Africa's poor growth performance has tended to shift the focus away from the failure of policy as such to a discussion of the failure of the African state. This has meant that the aid relationship has changed from a non-paternalistic one to one with extensive conditionalities and strict economic and political monitoring. While donors still are concerned with projects and macro policy, the development of political and market institutions are now much more in focus. Early critics of foreign aid, like Bauer and Friedman, argued that the development problem was not one of capital shortage, since that would have been solved by private capital markets, but one of shortcoming in political and economic institutions. Shortages of physical and human capital were just symptoms of these systemic shortcomings. They also argued that with poor institutions aid would be wasted or even inimical to growth by strengthening the position of the government against rival domestic constituencies. Adam and O'Connell (1997) note, however, that the government may hold back growth also by failure to intervene, for example to provide public goods.

Governments set the incentive regime and provide services. On both these counts African governments have performed poorly. How did the economic policies and the provision of public services evolve, and what role did aid play in this context?

Generally the environment has been anti-agriculture, and the elite that has been in power has generally been able to control the political scene without being challenged by the rural population. It was, however, under some pressure from its own narrow base of supporters. The external pressure for change was mostly weak. Instead aid probably even contributed to the insulation from pressure for change. It was eventually only the failures of the policy that forced changes. Government revenues fell drastically in several countries. Public salaries fell as employment in the sector increased. Aid inflows could not compensate for this, and eventually donors became unwilling to support government policies which were considered to be counterproductive. 
However, often when reforms were undertaken they were followed by urban protest and policy reversals. The governments then need to find domestic or external restraints on policy relapse. The use of domestic agents of restraint have proven difficult in Africa. Donors and the international financial institutions may help to guarantee the sustainability of reforms and to protect governments from domestic vested interests.

The level of public expenditures to GDP is generally higher in African countries than in comparable countries elsewhere. This does to a high degree depend on the inflow of aid, which typically tends to increase government consumption. There is no clear evidence that this contributes to long term growth, although one would suspect that for example improvements in human capital through education and health service provision should have beneficial long term effects.

Transport costs are considerably higher in Africa than in other regions. Electricity costs are higher than elsewhere and water supplies are unreliable. Projects in education have performed badly. Why is this? Partly the reasons are the same as for the private sector, that is a bad policy environment, which contributes to the low returns to public projects. Moreover, the government uses the public sector to further their own private interests and to build political support. Extensive corruption makes it hard to create an efficient system.

\section{The Character of Growth Enhancing Aid}

Can aid be growth enhancing in the African environment? Yes, the evidence above suggests that this is the case if there is a conducive policy environment. The last few years of structural adjustment have seen considerable improvements in the policy environment, and the private sector is slowly coming alive. However, progress with regard to institutional reform has been relatively slow. There are worries about the lack of transparency and good governance, although the process of reform and democratization should over time help improve the situation. A crucial issue for donors is thus how the relationship between them and the recipient countries should be set up to create and sustain a good environment for growth. We will here very briefly review a set of aspects that a donor needs to consider. 
When deciding on the amount of aid to allocate to a country, one needs to consider the absorptive capacity of the recipient. We have noted the poor state of the civil service in most African countries, while at the same time arguing that an effective civil service is a necessity. The direct approach is to try to help reform the system so that it can cope with the aid inflow. Second, one needs to use aid forms that are administratively simple and do not overburden the apparatus. Third, one could seek alternative channels for aid. In a situation with poor administrative capacity and a large debt burden it would also make sense to shift resources to debt service. This will make it possible for the recipient country to use more of its own resources for development, at the same time as reduced debt should stimulate private investment.

Donors should always ask where aid does have its comparative advantages? Where can aid be effectively used, and where is it better to leave the activity to domestic agents? Many African governments are overstretched. They cannot finance the whole public sector structure and pay the wages that are required for effective work in that sector. Donors should therefore be wary of creating new public sector institutions, but should instead concentrate on strengthening the core network. To improve public sector performance, there needs to be civil service reform. Politically, a reduction of the civil service is very difficult, because of retrenchment costs etc. Donors could support the reform process by helping to finance retrenchment or the cost of severance payments of redundant civil servants. This will be very healthy in the long term, and will also put a little capital in the hands of individuals who might do something productive with it. A similar opportunity exists in supporting retrenchment of workers and managers in downsized or privatized parastatals.

Sustainability of activities is the major worry with regard to project aid to Africa. All support requires careful assessment of affordability, given the level of external support likely to be forthcoming. If inconsistent and unsustainable standards of service provision are to be avoided, a sector approach is usually preferable to project aid. ${ }^{4}$ In situations where recurrent costs are a serious problem, donor support is especially appropriate for programmes which require higher expenditure now to permit lower expenditure later, and which therefore to some extent have their sustainability

\footnotetext{
4 "The justification for recurrent cost support in particular requires a careful evaluation of affordability and replicability of similar standards at the level of the sector as a whole. Donor supported islands of excellence in a sea of underfinancing are a poor use of resources, and ultimately unsustainable when donor fashions change. It is therefore desirable that proposals to support recurrent costs take a wider perspective, and it will normally be sensible to consider such proposals as part of a coordinated package for a whole sector or at least for an institution" . (ODA, 1994, pt 11)
} 
built in: Privatization, civil service retrenchment and infrastructure rehabilitation are examples of this.

Balance of payments (or budget) support may be an appropriate way of channelling money into economies where there is limited ability to absorb new projects at the same time as there are serious recurrent cost problems. It is important that countervalues are paid consistently. Failure to pay up undermines the stabilization efforts and softens the budget constraint. Budget support as well as support to projects on the priority list of the government, is essentially support to the government policy package. Given that this is the form of aid, the donor cannot shift the structure of expenditure directly. If this is to be achieved, he must instead specify conditions for minimum shares going to certain expenditures, or put a ceiling on other types of expenditures. Primarily one should consider expenditure shares for education and health. This should, however, not be done by individual donors unilaterally. Like with other general conditions of this nature, there should be coordination among the bilateral donors and the IFI's, for example in the context of the Public Expenditure Reviews.

Still, there are fairly strict limits as to how far donors can change the priorities of a recipient government. If they push through a programme that does not match the government's own priorities, the sustainability of aid activities will be undermined. Activities on which the government puts low priority run a high risk of decline once donors withdraw support.

Another type of public good, apart from education and health services, that it is worthwhile to support is the transport network. An extension and improvement of the road network in the peripheral areas would contribute significantly to the incomes of poor rural groups. This is a group for which it has turned out to be hard to find efficient forms for such support. This type of investment could crowd in investments, in the tradable sector. What will be the main issue in this area is, of course, whether the recipient government at different levels will have the capacity to maintain the extended network in the future. Capacity-building here would thus have to focus on strengthening the relevant institutions in this area. Support to economic infrastructure in general, not just to roads, often seem to work well, although one may at times be worried about the efficiency of the institutions or firms that are to handle the investments once they are there. Close attention should be given to the need for commercialization or privatization of the organizations involved. 
We have noted the problem of currency appreciation (Dutch Disease). The first best response is not less aid, but production subsidies to firms in the tradable sector, or simply export subsidies. One could consider export promotion in the form of both price and non-price incentives. Alternatively, one could try interest subsidies, that is, the introduction of a subsidy to banks to make it possible for them to charge lower interest rates for exporting firms. For this to be effective, however, the government must have the capability to handle it and the integrity to allocate the money on merit.

Donors should not try to do too complex things. It is too complex to intervene directly into production activities, be it agriculture or industry. It requires too much local knowledge. Donor interventions related to production should instead be directed to the creation of an enabling environment for the private sector. This may of course include the creation of institutions that can provide finance for the private sector, but the allocation of these resources should be left to the market. The private sector needs to be strengthened. One way to do this would be to set up charitable trust funds, support some venture capital institutions, or even support local banks. These could then function as financial institution that places its money in projects on a commercial basis. This would be one way to channel money into a country, without using the governmental channels or competing with them.

Aid may also help recipient countries to deal with risk. Many economies are, for example, exposed to uncertainty, and incomes may fluctuate due to swings in commodity prices or commodity production or because of international cycles. The recipient may therefore choose to use aid for consumptionsmoothing, rather than for investment, when the economy is facing problems. This should also be acceptable to the donor, when there is an emergency situation with, for example, drought and the threat of starvation. The fact that aid is available for such insurance may be growth enhancing, since it relieves the recipient country of the need to choose self-insurance strategies, that would have a cost in terms of growth. 


\section{A Changing Aid Relationship}

In the previous section we have noted a range of aspects that a donor needs to consider when devising an aid programme. However, since we have noted that the economic policy environment is crucial to the success of aid, the donor must also tackle the issue of how the relationship between donor and recipient effects the outcomes. Given the analysis above it seems reasonable to assume that this may be crucial to the degree of success of the aid programme. This issue is harder to deal with than the one about types of aid, so the discussion here has to be somewhat speculative.

We have noted that it is desirable that the recipient governments "own" the development programmes to a higher degree than they do at present. To achieve this, donors should delegate more responsibility to the recipients, while at the same time creating an incentive structures for good behaviour. At present, the donors feel a conflict between this type of solution and an effective handling of the projects that they finance. It is definitely the case that donors can take full control over projects and get them to work, but what will the long term implications of this be? Can effective project islands survive and have positive indirect effects on the surroundings, or does the hostile environment eventually force a project collapse? After all, well functioning projects in a failing overall structure are not proof of a good aid programme. This is particularly true in areas normally covered by government ministries, where an important output of any project should be a strengthening of government capacity to formulate and execute similar endeavours.

Project documents should include a discussion of how and when the withdrawal of support is to take place. All projects that start should have a specified endpoint in time (or an argument for indefinite or very long-term support).They should define the responsibility of the recipient. If the Government is not willing to commit itself, the project should never start. For the commitment to be credible, a greater share of the project cost should be covered by recipient from the very start.

Due to weak institutional capacity it has often been difficult to realise the aim that the recipient should handle projects. Responsibility for implementation has therefore at times been taken away from the recipient government. There is an obviously a conflict between giving responsibility to the recipient, and financial accountability. Ex post conditionality, that is a broader evaluation of results with pre-specified indicators, can provide strong incentives for reforms, and for a reestablishment of 
the government's reputation. However, donors should probably not shift completely towards ex post conditionality. There is also a role for ex ante conditionality - not least in terms of providing a means of transfer of advice and expertise and providing some pre-specified contractual obligations, but also for the reasons about the creation of constituencies which will "punish" governments for reneging on ex ante commitments. It is best to think of the aid and conditionality relationship as a two part contract with prior payments within a state-contingent ex ante-conditionality framework and then further aid flows based on ex post considerations.

With a shift in this direction, donors would need to work out a new type of guidelines for monitoring and auditing, since this would have to be of another form than current project evaluations. One could use simplified procedures for accounting, e. g. in terms of broader criteria of programme implementation. There is also a need for improving the design of ex ante conditionality to focus more on state-contingency in contracts. There are two important reasons for this. First, if conditionality is not state contingent then the typical conditionality contract will reward good luck and punish bad luck. If the donors are not in a position to separate good luck from "effort" then ex post conditionality will reinforce this, and there will be a bias in the allocation of aid money towards those enjoying good luck. The second reason is that the most convincing arguments for a shift towards ex post conditionality revolve around the question of reputation. Part of the inability to generate reputations is that the ex ante conditionality, which is not state contingent, typically does not allow any revelation of effort or commitment for the reasons discussed above. Credible governments have an incentive to demonstrate commitment or effort and this can be achieved better with state contingent contracts.

There will be some need for donor coordination also with regard to ex post conditionality. What is required is to find the appropriate balance between ex ante and ex post. For example, governments may have cash flow problems such that although they are committed to reform they are unable to implement reforms without additional aid resources provided ex ante. Similarly, although ex post conditionality does not' specify conditions for the potential recipient, it is still important that the rules of the game are made clear and that they are internally consistent between donors.

A shift towards ex post conditionality would also make it easier to allocate aid as general budget support, which we have argued may be desirable for a number of reasons. In the case of ex post conditionality, once the decision to disburse is made - ex post - the donor must logically relinquish 
any claim on how the resources are allocated within the country. If the government is truly of the "right type" then it will manage the resource flow and the countervalue funds in a manner consistent with the wishes of the donor. If the recipient government spends it all on non-productive expenditure, inflation and patronage, then (a) the donor has misjudged the type of the country and (b) the country will not win the contest for aid money the next time. With the ex post approach the rules of the game will allow the donor to distinguish good and committed governments from bad ones. ${ }^{5}$ A shift towards a general form of support, giving the recipient government increased responsibility and ownership could help restore the quality of government. However, if this approach is chosen, then the donor must be prepared to walk out if the situation deteriorates sufficiently. Here, however, we have another time inconsistency problem, sometimes referred to as the Samaritan's Dilemma. It may be hard to avoid coming in to rescue innocent sufferers of the government failure, and thus to function as an agent of restraint on the government.

An understanding of how the political process works is a crucial factor in the formulation of an effective donor-recipient relationship. Adam and O'Connell (1997) discuss this issue extensively. A problem as we have noted above has been the extensive executive discretion in Africa. When this is linked to uncertainly about the process of political succession, the absence of formal agencies of restraint minimizing such discretion raises uncertainly. Leaders with long horizons tend to internalize the collective interests in economic growth, while leaders with short horizons tend to sacrifice long term interests in order to maximize their own short-term rents. For example, the higher insecurity of the Moi regime in Kenya relative to the Kenyatta regime has tended to increase predatory behaviour under Moi (Bigsten and Moene, 1996). There is a conflict between executive discretion and contestability: "Thus policies of exchange rate unification, trade liberalization, financial liberalization, privatization and in particular the support for competitive elections, all undermine the scope for executive discretion, improving the capacity to commit to policy measures, but at the cost of making the political system more contestable, which may lead to only partial implementation and fail to reduce the uncertainly faced by the private sector" (Adam and O'Connell, 1997). There is thus a tension between the gains accruing from reforms which solves the government commitment problems and the costs of increased contestability on the other.

There is one caveat to the argument that there should be no conditions on disbursement of the ex post conditionality and that relates to the Dutch Disease problems. Suppose for example the attribute the donor is rewarding ex post is export diversification. In this case the winner will receive an aid "price" which by appreciating the real exchange rate may undermine the benefits gained in pursuit of the price. It may be necessary, therefore, to ensure that the implicit tax on exporters associated with the aid inflow is offset by some subsidy or compensation, wither by way of a subsidy on exported output, export production (possibly on the cost of credit) or on investment. 
Adam and O'Connell conclude that for a developmental state unconditional transfers reduce distortions, thereby delivering benefits that are larger than those attached simply to a consumption transfer. But if the state is not fully representative, increased aid may also change the character of domestic taxation so that distortionary taxes are on the margin financing not only the public good but also transfer to the favoured group. Their conclusion thus supports the notion that aid tends to politicize life in developing countries, and this may in turn have detrimental effects on the private sector's ability to act as an agent of restraint.

Conditionality may first provide the recipient with a way of committing credibly to a course of action that is in the recipient's own interest, independently of the aid inflow. Second, it may support flows of resources in the face of a conflict of interest between the donor and the recipient, when the former is interested in the general welfare of the population and the latter mainly concerned with a certain section of the population. At least when the donor has a strong bargaining position, conditionality in the Adam and O'Connell model would lead to a reduction in distortionary taxation, with a simultaneous reduction in transfers to the governments support groups. Development outcomes would be better.

Here there is again a time inconsistency problem. Graduation from aid dependency is normally the long term aim of the donor, but to support such a graduation the donor would have to define policy choice over the policy process itself. This would imply conditionality concerning, for example, constitutional and judicial reforms and supporting developments in the civil society. These could include a freer press and independent trade unions as well as policies aimed at establishing interest groups outside of government control.

The dilemma with regard to conditionality is that it can, in the short term, function as an agent of restraint, but in the longer term it may instead crowd out the development of domestic agents of restraint on the actions of the recipient government. If aid is to be effective, donors must find ways to combine a move towards increasing self-reliance on the part of the recipients with the realization of the other goals for aid that the donor has, normally the improvement of welfare of the recipient population. This will only be possible if the social and political environment in the recipient country is such that predation tendencies of the recipient governments can be held in check. With the more open social climate in much of Africa, the chances for this are now much better than a decade ago. Democracy may thus make it easier to make aid efficient. 


\section{Concluding Remark}

So far, aid has not been shown to have had a major positive impact on growth in Africa, although its impact via policy change may have been important. The conclusion of Burnside and Dollar is that if donors are concerned with growth and poverty reduction, then they should put high weight on the economic policies of the recipient countries. The recent shifts in policy in Africa have been in the "right" direction, which would suggest that the growth environment and thus the environment for efficient aid has improved. It is thus possible that there may be a stronger effect of aid on growth in the future. It will be particularly important if it can help crowd in private foreign and domestic private investment. Aid can only be a supplement to those resources. One the growth environment is in place, donors may be able to cut back on aid and change the relationship to more of a normal commercial and political links. We are not there yet, but we seem to be in a position where there is a better chance than before that aid can bring about growth. That is not the time to withdraw support. 


\section{References}

Adam, C., Bigsten, A., Collier, P., Julin, E., O’Connell, S. (1994a), Evaluation of Swedish Development Cooperation with Tanzania, SASDA, Ds 1994:113, Foreign Office, Stockholm.

Adam, C., Andersson, P-Å., Bigsten, A., Collier, P., O’Connell, S. (1994b), Evaluation of Swedish Development Cooperation with Zambia, SASDA, Ds 1994:114, Foreign Office, Stockholm.

Adam, C., O’Connell, S. (1997), “Aid, Taxation and Development: Analytical Perspectives on Aid Effectiveness in Sub-Saharan Africa", Working Paper no 97-5, Centre for the Study of African Economies, Oxford University, Oxford.

Bigsten, A. (1993), "Regulations versus Price Reforms in Crisis Management. The Case of Kenya", in M. Blomström and M. Lundahl (eds.), Economic Crisis in Africa: Perspectives on Policy Responses, Routledge, London.

Bigsten, A., Moene, K-O. (1996), "Growth and Rent Dissipation: The Case of Kenya", Journal of African Economies, 5(2).

Bonnick, G.G. (1997), Zambia Country Assistance Review. Turning an Economy Around, OED, World Bank Operations Evaluation Study, World Bank, Washington DC.

Boone, P. (1994), "The Impact of Foreign Aid on Savings and Growth", London School of Economics, mimeo.

Boone, P. (1996), "Politics and the Effectiveness of Foreign Aid", European Economic Review 40(2).

Burnside, C., Dollar, D. (1997), “Aid, Policies and Growth”, Policy Research Working Paper no 1777, World Bank, Washington DC.

Claessens, S. Naude, D. (1993), "Recent Estimates of Capital Flight", Policy Research Working Paper no 1186, World Bank, Washington DC. 
Collier, P. Gunning, J.W. (1997), "Explaining African Economic Performance”, Working Paper no 97-2, Centre for the Study of African Economies, Oxford University, Oxford.

Easterly, W., Levine, R. (1995), "Africa's Growth Tragedy: a Retrospective, 1960-89", Policy Research Working Paper no 1503, World Bank, Washington DC.

Easterly, W.R., Levine, R. (1996), “Africa’s Growth Tragedy: Policies and Ethnic Divisions”, World Bank, mimeo.

Mosley, P. (1987), Overseas Aid: Its Defence and Reform, Wheatsheaf Books, Brighton.

Mosley, P., Hudson, J., Horrel, S. (1987), “Aid, the Public Sector and the market in Less Developed Countries", Economic Journal 97(2).

ODA (1994), “Aid, hidden transfers and conditionality”, mimeo.

Paldam, M. (1997), “The Micro-Efficiency of Danish Development Aid”, Working Paper No. 199713, Department of Economics, University of Aarhus.

Riddell, R. (1987), Foreign Aid Reconsidered, James Currey, London.

Rodrik, D. (1989), “Credibility of Trade Reform - a Policy Makers Guide”, The World Economy 12.

Sachs, J.D., Warner, A. (1995), "Economic Reform and the Process of Economic Integration", Brooking Paper on Economic Activity 1.

White, H. (1992), “The Macroeconomic Impact of Development Aid: A Critical Survey”, Journal of Development Studies, 28(2).

White, H. (ed.) (1998), Aid and Macroeconomic Performance. Theory, Empirical Evidence and Four Country Cases, Macmillan, London.

World Bank (1997), World Development Report 1997, Washington D.C. 